\title{
IAMJ
}

INTERNATIONAL

AYURVEDIC

MEDICAL JOURNAL

\section{CLINICAL STUDY OF THE EFFECT OF NASYA KARMA IN THE MANAGEMENT OF CERVICAL SPONDYLOSIS WITH SPECIAL REFERENCE TO MANYASTAMBHA}

\author{
Paresh R. Deshmukh ${ }^{1}$, Kavita K. Fadnavis ${ }^{2}$ \\ ${ }^{1}$ Associate Professor, Department of Kayachikitsa, SVERDCT's Swami Vivekanand Ayurved Medical College, \\ Pargaon, Shrigonda, Ahmednagar, Maharashtra, India \\ ${ }^{2}$ Associate Professor, Department of Kaumarbhritya, C.S.M.S.S. Ayurved College, Kanchanwadi, Aurangabad, \\ Maharashtra, India
}

Corresponding Author: drpareshd@gmail.com

https://doi.org/10.46607/iamj02p5022021

(Published Online: January 2021)

Open Access

(C) International Ayurvedic Medical Journal, India 2021

Article Received:12/12/2020 - Peer Reviewed:18/12/2020 - Accepted for Publication:25/12/2020

(A) Check for updates

\section{ABSTRACT}

Human life has become more stressful these days. Sedentary lifestyle, occupational factors are playing a large role in increased prevalence of the common degenerative disorder of Cervical Spine i.e. Cervical Spondylosis. In Ayurvedic view, it can be correlated with Manyastambha which is a Vataja Nanatmaka Vikara. Degeneration means Apatarpana in Ayurveda. It needs to be treated with Brimhana Therapy. And Urdhvajatrugata Vyadhis are best treated with Nasya according to Ayurveda. So, taking all these factors into consideration, Brimhana Nasya Karma with Ksheerabala Taila was tried to alleviate the signs and symptoms of patients having Cervical Spondylosis. Assessment was done with regard to pain in neck and shoulder, tingling and numbness in hands and headache alongwith various angles of rotation of neck. The data was collected before and after administration of Nasya karma. The 15 days trial was proved to be significantly efficacious in reducing signs and symptoms of cervical spondylosis.

Keywords: Cervical Spondylosis, Manyastambha, Vataja Nanatmaka Vikara, Apatarpana, Brimhana Nasya, Ksheerabalataila. 


\section{INTRODUCTION}

In these days, Cervical spondylosis is one of the most common disorders of cervical spine. It is characterized by severe pain in neck \& shoulders, rigid neck, burning \& tingling sensation at upper limb \& sometimes occipital headache ${ }^{1}$. Though it is a degenerative osteoarthritis of joints between the cervical vertebra and is generally associated with ageing, in India, the younger patients of cervical spondylosis are increasing day by day. ${ }^{2}$ So, Along with ageing, the associated risk factors in young patients are Sedentary lifestyle, poor posture \& occupational factors such as Computer keyboarding, cell phone texting etc. played a large role in increased prevalence of neck pain in past 20 years. ${ }^{3}$ Cervical spondylosis affects quality life of a person. A cohort study signifies that Cervical Spondylosis myelopathy may produce anxiety and depression. ${ }^{4}$ According to modern science, treatment is mostly conservative. It consists oral analgesics \& physiotherapy. In some cases, cervical collar is advised. Surgery is rarely done. ${ }^{5}$ According to Ayurvedic Samhitas, Cervical Spondylosis resembles Manyastambha (rigid neck) which is a Vataj Nanatmaka disorder (disorder of Vata). Manyastambh is a condition where the vitiated Vata lodges in the neck region due to wrong sleeping positions, use of large pillows, Diwaswapa, continuously watching downwards or upwards for a longer period of time causing over stretching of Neck and which leads to Shosha (desiccation) of muscles of the neck. Vyaana Vayu is responsible for the movements of the body. ${ }^{6}$ Neck is a body part above clavicle so in Ayurveda literature it comes under Urdhvajatrgata Vikara (diseases above neck region). Nasya Karma (Nasal Medication) is widely employed in Ayurveda. It is the only therapeutic measure among Panchakarma which is instilled into the nostrils and has a direct access to head. In all the Urdhvajatrugata Vikaras, all the Acharys unanimously highlighted Nasya Karma to be effective. Acharya Charaka mentions all Urdhvajatrugata Vikara specially Vatajavikara like Manyastambha etc. are to be treated with Nasya Karma. $^{7}$ While Acharya Vagbhata appreciates Nasya as useful in keeping Greeva and
Skandha (Neck \&shoulder) healthy ${ }^{8}$.In Cervical Spondylosis, degeneration can be implied as Apatarpana (emaciation) according to Ayurveda. Hence condition of Cervical spondylosis which is degenerative one need Brimhana (nourishing) therapy. ${ }^{9}$ Vagbhata specifically mentioned Brimhana Nasya being useful in treating Vataja Shoola (pain) like conditions. ${ }^{10}$ Keeping all these factors in mind, it was hypothesized that Brimhana Nasya Karma may prove effective in relieving symptoms of Manyastambha like 'Ruk' (pain) and 'Stambha' (rigidity) in the patients of Cervical spondylosis. So, the present study entitled "Clinical study of the effect of Nasya Karma in the management of Cervical spondylosis with special reference to Manyastambha" was undertaken.

\section{Material \& Methods}

Study Design- The study is single group clinical trial., Total 22 patients were registered in the study. There were 2 dropped patients who discontinued the treatment.

Source of Data- 20 diagnosed patients of Cervical Spondylosis coming under inclusion criteria and approaching the OPD of SVERDCT's Swami Vivekanand Ayurved Medical College, Shrigonda, Ahmednagar were selected for the study irrespective of age, Sex, Religion and Socio-economic status.

\section{Inclusion Criteria -}

- Patients having signs and symptoms of Manyastambha,

- Patients who are willing for Nasya Karma.

\section{Exclusion Criteria}

IVDP of Cervical spine, Ankylosing spondylosis, Nasal polyps, Urdhvajatrugata Raktapitta (bleeding through upper orifices of body), Nava Peenasa (initial stage of rhinitis) and all the Nasya Anarha (contraindications of Nasal Medication) conditions., Unwilling patients for Nasyakarma.

Method of Collection of Data- A special proforma containing details necessary for the study was prepared. Investigations were carried out as and when necessary. 
Duration of the Therapy - 15 days

Intervention- Nasya Karma-The patients were subjected to the following protocol of Nasya Karma which was adopted as per Acharya Vagbhata mentioned in Nasyavidhi ${ }^{11}$

1. Nasya Poorva Karma (Preparatory measures for Nasya) -Urdhvajatru Snehabhyanga (Massage of Head, Neck and Face) - with Dhanvantara taila $^{12}$ for 15 mins. Which was immediately followed by Urdhvajatru Svedana (Hot fomentation of head, Neck and Face) - with Nadisweda (fomentation with steam through a tube) of Nirgundi Kwatha (Decoction) for 5 mins.

2. Nasya Pradhana Karma (Main Procedure Nasya) -For Brimhana effect, Ksheerabalataila was selected from Sahastrayogam ${ }^{13}$. Madhyama Matra of Marsha Nasya i.e. 8 drops were selected. ${ }^{118}$ drops of lukewarm Ksheerabalatailam was instilled in each nostril of the patient.

3. Nasya Pashchat Karma (Post-operative Procedure) -Patients were allowed to spit the accumulated remnants of Nasya Taila if some., Pashcat Svedana of Urdhvajatru with Nirgundi Kwatha Nadi Sweda for 5 mins., Kavala Dharana (gargling)with lukewarm water was performed for 5 mins in each patient.

Criteria for Assessment-The assessment criteria were divided into two categories as - Subjective Criteria and Objective Criteria.
A. Subjective Criteria -

\section{Pain in Neck and Shoulder -}

0- $\quad$ No pain in Neck and Shoulder

1- $\quad$ Mild pain in Neck and Shoulder

2- $\quad$ Moderate pain in Neck and Shoulder

3- $\quad$ Severe pain in Neck and Shoulder

2. Tingling and numbness in hands -

0 - $\quad$ No tingling and numbness in hands

1- $\quad$ Mild tingling and numbness in hands

2- $\quad$ Moderate tingling and numbness in hands

3- $\quad$ Severe tingling and numbness in hands

\section{Headache -}

0- No headache

1- Mild headache

2- Moderate headache

3- Severe headache

B. Objective Criteria for Neck stiffness -

1. Angle of Flexion, 2. Angle of Extension, 3. Angle of Rotation, 4. Angle of lateral rotation (left side)

5. Angle of lateral rotation (right side)

Before commencing treatment, all the assessment criteria were recorded, and the data was termed as Before Treatment. (B.T.). While the data recorded of all the assessment criteria after completion of therapy was termed as After Treatment. (A.T.)

Data Analysis- The data collected was rendered to Master Chart and tables were constructed. For subjective data, "Wilcoxon's signed Rank Test" was applied whereas "Paired $\mathrm{t}$ - Test" was applied for the analysis of Objective data.

\section{Observation and Results -}

Table 1: showing Age wise and Gender wise Distribution of 20 patients of Cervical spondylosis

\begin{tabular}{|l|l|l|l|}
\hline Age & Male & Female & Total \\
\hline $21-30$ years & 1 & 0 & 01 \\
\hline $31-40$ years & 3 & 2 & 05 \\
\hline $41-50$ years & 3 & 2 & 05 \\
\hline $51-60$ years & 4 & 2 & 06 \\
\hline $61-70$ years & 0 & 2 & 02 \\
\hline $71-80$ years & 1 & 0 & 01 \\
\hline
\end{tabular}

The study shown that the maximum patients were Male i.e. $60 \%$., Most of the patients $(80 \%)$ were from middle age group - 31 to 60 years of age. 
Table 2: Showing Results of 'Wilcoxon Signed Rank Test' for the symptom Neck and Shoulder pain, Tingling and numbness in hands and Headache

\begin{tabular}{|l|l|l|l|l|l|}
\hline Symptom & B.T. Mean & A.T. Mean & S.D. & Z value & P value \\
\hline Pain in Neck and Shoulder & 1.75 & 0.65 & 19.33 & 3.51 & $\mathrm{P}<0.05$ \\
\hline Tingling and Numbness in hands & 1.56 & 0.92 & 17.60 & 3.20 & $\mathrm{P}<0.05$ \\
\hline Headache & 1.62 & 0.76 & 18.30 & 3.38 & $\mathrm{P}<0.05$ \\
\hline
\end{tabular}

It is clear from above table that all the signs and symptoms of Cervical Spondylosis viz. Pain in Neck and Shoulder, Tingling and numbness in hands and Headache showed significant improvement with $\mathrm{p}<0.05$.

Table 3: showing Results of 'Paired t Test' for the symptom Neck Stiffness

\begin{tabular}{|l|l|l|l|l|l|l|}
\hline & \multicolumn{2}{l}{ Mean } & Diff. Of Mean \pm SD & SEd & t value & $\mathrm{p}$ value \\
\cline { 2 - 8 } & BT & AT & & & & \\
\hline Angle of Flexion & 152.6 & 160.20 & $7.8 \pm 9.68$ & 1.46 & 4.16 & $\mathrm{p}<0.001$ \\
\hline Angle of Extension & 135.10 & 141.20 & $6.1 \pm 10.10$ & 1.76 & 3.96 & $\mathrm{p}<0.001$ \\
\hline Angle of Lat. Extension (left) & 131.50 & 137.50 & $6.0 \pm 8.80$ & 1.34 & 4.47 & $\mathrm{p}<0.001$ \\
\hline Angle of Lat. Extension (Right) & 133.20 & 140.20 & $7.0 \pm 9.01$ & 1.60 & 4.42 & $\mathrm{p}<0.001$ \\
\hline
\end{tabular}

This table clearly shows that Neck stiffness decreases effectively in every angle of rotation of neck with the help of Ksheerabala Taila Nasya Karma. The angles of movements of neck shown improvement with $\mathrm{p}<0.001$ which is highly significant.

\section{DISCUSSION}

The study shows that number of male patients was more probably because of the etiological factors of cervical discomfort like excessive usage of vehicles on an uneven road, sedentary lifestyle, computer work, etc. are more common in them. Most of the patients were found from middle age group.It can be seen that proper Snehana and Swedana karma is very essential part of Nasya Karma. Snehabhyanga with Dhanwantara Taila ${ }^{12}$ helped in relieving all Vataj symptoms which is mentioned by Sahastrayogam. While Swedana helped in relieving Stambha of neck i.e. Neck Rigidity. ${ }^{14}$ KsheerabalaTaila itself has a Brimhana Property. In Sahastrayogam, Ksheerabala Taila $^{12}$ is said to be useful for Nasya Karma in 80 types of Vatavyadhis. So, it probably helped in decreasing the degenerative changes in Cervical Spondylosis along with Vatashamamak (alleviation of Vata) and Brimhana effect. The overall study shows significant results in subjective criteria viz. Neck and shoulder pain, tingling and numbness in hands and headache with $\mathrm{p}<0.05$. Objective criteria i.e. various angles of rotation of neck also shown significant improvement with $\mathrm{p}<0.001$ with proper Snehabhyanga, Swedana and Nasya Karma. Thus, it can be said that present study entitled "Clinical study of the effect of Nasya Karma in the management of Cervical spondylosis with special reference to Manyastambha" shown encouraging results.

\section{CONCLUSION}

Cervical spondylosis or Manyastambha has increasing prevalence day by day which affects quality of life. Nasya Karma along with preoperative and postoperative procedures exhibit better results including significant reduction in signs and symptoms. The therapy did not show any side effect. It is a relatively cost-effective therapy than other available therapies for Cervical Spondylosis.

\section{REFERENCES}

1. Aspi F Golwalla and Sharukh A Golwalla, Golwalla's Medicine for Students, 25 ${ }^{\text {th }}$ edition, 2017, Edited by Milind Y Nadkar, Published by JAYPEE The Health Science Publisher, New Delhi, Page No. 592.

2. www.thehindubusinessline.com $>$ article- $\quad(20 \%$ of people with back and neck conditions are in age goup of 16 - 34) Q1 Spine Clinic's World Spine Day 2017 Insights report: Published on October 16, 2017; Updated on January 08, 2018. Cited on December 02, 2020.

3. Ccryn.gov.in $>$ default $>$ files pdf Cervical Spondylosis- Naturopathy and Yogic Management of 
Cervical Spondylosis- CCRYN; cited on December 02, 2020.

4. Cervical spondylotic myelopathy, Depression and Anxiety: A Cohort analysis of 89 patients - Michael R. Stoffman, Mark S. Roberts, Joseph T. King Neurosurgery, Volume 57, Issue - 2, Published in Aug 01, 2005, Page No. - 307 - 313.Web address https://doi.org/10.1227/01.NEU.00016664.19662.43

5. Davidson's Principals and Practice of Medicine, $23^{\text {rd }}$ edition, 2018, Edited by Stuart H.Ralston, Ian D. Penman, Mark WJ Strachall, Richard P. Hobson, Published by Elsevier Publication, Page No. - 1134.

6. Agnivesha, Charak Samhita- Part - 2, Chikitsasthana, Adhyaya 28, Reprint edition, 2009, Edited with Hindi commentary by Acharya Vidyadhara Shukla and Prof. Ravi Dutt Tripathi, Published by Chaukhambha Sanskrit Pratishthana, Delhi, Page No. -689.

7. Agnivesha, Charak Samhita- Part - 1, Sootrasthana, Adhyaya 5, Reprint edition, 2002, Edited with Hindi commentary by Acharya Vidyadhara Shukla and Prof. Ravi Dutt Tripathi, Published by Chaukhambha Sanskrit Pratishthana, Delhi, Page No. -98.

8. Vagbhata, Ashtangahridayam, Sootrasthana Adhyaya - 20,14 $4^{\text {th }}$ edition, 2003, Edited with Vidyotini Hindi Commentary by KavirajaAtrideva Gupta, Edited by Yadunandana Upadhyaya, Published by Chaukhambha Sanskrit Pratishthana, Varanasi, Page No. 130.

9. Vagbhata, Ashtangahridayam, Sootrasthana Adhyaya14, 14 $4^{\text {th }}$ edition, 2003, Edited with Vidyotini Hindi Commentary by Kaviraja Atrideva Gupta, Edited by Yadunandana Upadhyaya, Published by Chaukhambha Sanskrit Pratishthana, Varanasi, Page No. 100.

10. Vagbhata, Ashtangahridayam, Sootrasthana Adhyaya20, 14 $4^{\text {th }}$ edition, 2003, Edited with Vidyotini Hindi Commentary by Kaviraja Atrideva Gupta, Edited by Yadunandana Upadhyaya, Published by Chaukhambha Sanskrit Pratishthana, Varanasi, Page No. 127.

11. Vagbhata, Ashtangahridayam, Sootrasthana-Adyaya20, 14 $4^{\text {th }}$ edition, 2003, Edited with Vidyotini Hindi Commentary by Kaviraja Atrideva Gupta, Edited by Yadunandana Upadhyaya, Published by Chaukhambha Sanskrit Pratishthana, Varanasi, Page No. 128 - 129.

12. Dr. D. B. Panditrao, Sahastrayogam-Hindi translation, Prakaranam - 5, Reprint edition, 2011, ISBN- 978-816-8, Published by R. K. Print House, Noida, U.P., Page No.- 51.

13. Dr. D. B. Panditrao, Sahastrayogam- Hindi translation, Prakaranam- 5, Reprint edition, 2011, ISBN- 978-81-
6-8, Published by R.K. Print House, Noida, U.P., Page No.- 292.

14. Agnivesha, Charak Samhita, Part - 1, Sootrasthana, Adhyaya 13, Reprint edition, 2002, Edited with Hindi commentary by Acharya Vidyadhara Shukla and Prof. Ravi Dutt Tripathi, Published by Chaukhambha Sanskrit Pratishthana, Delhi, Page No. -309.

\section{Source of Support: Nil Conflict of Interest: None Declared}

How to cite this URL: Paresh R. Deshmukh \& Kavita K. Fadnavis: Clinical Study of The Effect of Nasya Karma in the Management of Cervical Spondylosis with Special Reference to Manyastambha. International Ayurvedic Medical Journal \{online\} 2021 \{cited January, 2021\} Available from: http://www.iamj.in/posts/images/upload/2658_2662.pdf 